2001

\title{
Two Fallacies About DNA Data Banks for Law Enforcement
}

David H. Kaye

Penn State Law

Follow this and additional works at: http://elibrary.law.psu.edu/fac_works

Part of the Criminal Law Commons, Evidence Commons, and the Science and Technology Law Commons

\section{Recommended Citation}

David H. Kaye, Two Fallacies About DNA Data Banks for Law Enforcement, 67 Brook. L. Rev. 179 (2001).

This Article is brought to you for free and open access by the Faculty Works at Penn State Law eLibrary. It has been accepted for inclusion in Journal Articles by an authorized administrator of Penn State Law eLibrary. For more information, please contact ram6023@psu.edu. 


\title{
COMMENTARY
}

\section{TWO FALLACIES ABOUT DNA DATA BANKS FOR LAW ENFORCEMENT ${ }^{*}$}

\author{
David H. Kaye ${ }^{t}$
}

\section{INTRODUCTION}

As J.P. was entering her townhouse on a chilly Minnesota morning, a man grabbed her, held a metal object against her neck, forced her into her car, and pulled a stocking cap over her face. He threatened her with a screwdriver and raped her. Troy Bradley Bloom was out of prison after serving nine years for a series of sexual assaults in Minneapolis. His DNA profile was in Minnesota's sexual offender DNA data base. A computerized search revealed that the sample of Bloom's DNA on file matched semen stains found in the car. Bloom was arrested and convicted of burglary, kidnapping, and criminal sexual conduct. "Without the database," the prosecutor reported, "there is no way he would have been convicted."

Late for school, a seven-year-old girl was hurrying along Milwaukee's South 18th Street, going as quickly as she could

* C2001 David H. Kaye. All Rights Reserved.

$\dagger$ Regents' Professor, Arizona State University; Fellow, Center for the Study of Law, Science, and Technology. I am grateful to Edward Imwinkelried and Michael Smith for contributions to portions of this comment and to John Butler and George Sensabaugh for information on the CODIS core STR loci.

'David Chanen, Court of Appeals Upholds '94 Rape Conviction That Used DNA Analysis, STAR TRIB. (Minneapolis-St. Paul), Feb. 1, 1996, at 3B (quoting Assistant Hennepin County Attorney Steve Redding). 
in her puffy snowsuit. A man appeared suddenly, wrapped his hand around her right wrist and pulled her behind a house. $\mathrm{He}$ raped her. Six years later, just before Wisconsin's statute of limitations for sexual assault was about to run, an arrest warrant was issued for "John Doe, unknown male, with matching deoxyribonucleic acid ("DNA") at genetic locations D2S44, D4S139, D5S110, D10S28, D1S7 and D17S79." The unknown male is still at large, but Norm Gahn, the prosecutor who initiated the practice of issuing "John Doe" DNA warrants, observed that "[s]omeday, somewhere, we hope this guy comes up in somebody's databank. And we'll nail him." ${ }^{2}$

When law enforcement authorities began building DNA data bases in the early 1990 s, only people like Bloom who were convicted of serious sexual crimes were included. Before long, many states began collecting DNA from murderers, then other violent felons, and, most recently, all felons and even some misdemeanants. Extensions of the data bases followed from the realization that DNA evidence is more common at crime scenes than was at first thought and that recidivism rates for many felonies are at least as large as those for most sex crimes. ${ }^{3}$ Britain has assembled a large data base by taking DNA samples at the time of an arrest. Not only did the DNA profiles of arrested property offenders often yield data base "hits" in rape cases, but the growing data base produced even more "hits" in burglaries and vehicle thefts. ${ }^{4}$ Bills expanding data 2000 , at A1.

${ }^{2}$ Eric Slater, Rape Case DNA Tests the Limits, LOS ANGELES TIMES, Feb. 11,

${ }^{3}$ For example, The Bureau of Justice Statistics examined the arrest and conviction records of a representative sample of all prisoners released in 1983 from prisons in eleven states. See LAWRENCE A. GREENFELD, U.S. DEP'T OF JUSTICE, SEX OFFENSES AND OFFENDERS: AN ANALYSIS OF DATA ON RAPE AND SEXUAL ASSAULT 26 (1997). The rates of re-arrests and re-convictions for rapists were $52 \%$ and $36 \%$, respectively. For all violent offenders, the rates were still higher- $60 \%$ and $42 \%$, respectively. Id. at 27; see also Katherine K. Baker, Once a Rapist? Motivational Evidence and Relevancy in Rape Law, 110 HARV. L. REv. 563, 578-80 (1997); Thomas J. Reed, Reading Gaol Revisited: Admission of Uncharged Misconduct Evidence in Sex Offender Cases, 21 AM. J. CRIM. L. 127, 149, 154-55 (1993); Paul R. Rice, The Evidence Project: Proposed Revisions to the Federal Rules of Evidence with Supporting Commentary, 171 F.R.D. 330, 479 (1997). However, these data do not exclude the possibility that even if sex offenders are not distinctive in terms of the overall proportion of recidivists, they commit a relatively large number of sex offenses per recidivist in the follow-up period. See Amitai Etzioni, Address at Conference on DNA and the Criminal Justice System, Cambridge, Mass., Nov. 21, 2000.

${ }^{4}$ See David Werrett, The Strategic Use of DNA Profiling, Address to the 18th 
bases to include arrestee profiles are pending in several states. ${ }^{5}$ Louisiana already has legislation authorizing it. ${ }^{6}$ California law provides for DNA records to be kept in the state's data base while charges are pending, and a Texas statute requires the collection of DNA specimens from everyone indicted for certain felonies, including kidnapping and sexual assault. ${ }^{8}$

Each DNA data base expansion has triggered sharp debate. Law enforcement officials often view DNA sampling as no more problematic than fingerprinting. Civil liberties advocates and other commentators decry "unfettered government-sponsored bioinvasion" and worry that DNA data

International Congress on Forensic Haemogenetics, San Francisco, Cal. (Aug. 19, 1999); see also Paul Ferrara, DNA Typing in Action: Databasing in the Commonwealth of Virginia, PROFILES IN DNA, June 1999, at 2, 4 ("greater than sixty percent of the hits from violent offender cases match database samples from convicted burglars-not violent offenders").

${ }_{5}$ A bill introduced early in 1999, in the Connecticut General Assembly would require the collection of DNA from those arrested of any criminal offense. The bill does not require destruction of the sample unless the arrestee is not later "convicted of an offense." S.B. 315, 1999 Leg., Jan. Sess. (Conn. 1999). A bill introduced in the North Carolina General Assembly would require that DNA samples be taken from all individuals arrested for various felonies. S.B. 95, 2001-2002 Leg., Reg. Sess. (N.C. 2001). Section 6 of the bill would allow individuals to petition for expungement of a "DNA record or profile" after "the felony arrest or conviction ... has been reversed and the case dismissed." Id. New York Senate Bill 1795, introduced January 30, 2001, would require individuals arrested for a variety of felonies to provide a sample of blood for DNA testing; cf. N.Y.A. $4486 \S 2,2001$ Leg. Sess. (2001) (providing that the executive branch develop "a statewide strategic plan for requiring any person arrested for an offense for which the fingerprints of the person are required to be taken ... also be required to provide at the time of arrest, a sample appropriate for DNA testing to determine identification characteristics specific to such person for inclusion in the state DNA identification index").

${ }^{6}$ See 15 LA. REV. STAT. $\$ 609$ (A) (West 1999) ("A person who is arrested for a felony sex offense or other specified offense on or after September 1,1999, shall have a DNA sample drawn or taken at the same time he is fingerprinted pursuant to the booking procedure."). Despite the language of the statute, it was reported that the state will delay implementing the requirement for lack of funding and testing facilities. See Guy Gugliotta, A Rush to DNA Sampling; Vital Police Tool? Affront to Liberty? Both?, WASH. PoST, July 7, 1999, at A1, available at 1999 WL 17012783.

${ }^{7}$ See CAl. Penal CoDE $\S 297(b)(3)$ (West 2001) ("For the purposes of this subdivision, 'a suspect' means a person against whom an information or indictment has been filed for one of the crimes listed in subdivision (a) of Section 296. For the purposes of this subdivision, a person shall remain a suspect for two years from the date of the filing of the information or indictment or until the DNA laboratory receives notification that the person has been acquitted of the charges or the charges were dismissed.").

${ }^{8}$ TEX. GOV'T CODE ANN. § 411.1471 (effective Sept. 1, 2001).

${ }^{9}$ Paul R. Billings, Editorial, DNA Data Banks Would Taint Justice, BOSTON GLOBE, Jan. 14, 1999, 1999 WL 6043488. 
banks will expose "[w]ho I am, my biological potential, my health situation, my paternity, my race, [and the] most profound personal secrets. ${ }^{.10}$ The more extreme critics even depict the data base statutes as countenancing medical experimentation on unconsenting human subjects in violation of the Nuremberg Code and basic ethical principles. ${ }^{11}$

In Legal and Policy Issues in Expanding the Scope of Law Enforcement DNA Data Banks, Professors Mark A. Rothstein and Sandra Carnahan seek a safe course through this sea of rhetoric. ${ }^{12}$ They presume that "DNA data banks of increasingly broad scope would help to solve more crimes," and they are not prepared to dismiss out-of-hand these data bases as unconstitutional. ${ }^{14}$ Nevertheless, they insist that "public policy demands" that only a small fraction of the population-convicted sex offenders and violent felons-have identifying DNA types on file, that the types consist strictly of noncoding DNA regions, and that the samples themselves be destroyed..$^{15}$ These policy conclusions are presented as part of a larger list of nine commandments for law enforcement DNA data bases that would restrain the government in its use of genetic information. ${ }^{16}$

${ }^{10} 60$ Minutes: DNA Data Banks Keep Track of Criminals, Cause Controversy (CBS television broadcast, Apr. 18, 1999), available at 1999 WL 16209028 (statement of Professor Nadine Strossen, ACLU President); see also Dial v. Vaughn, 733 A.2d 1, 11 ( $\mathrm{Pa}$. Commw. Ct. 1999) (dissenting opinion) ("DNA samples will reveal everything about a person"). For criticism of such "genetic essentialism," see David H. Kaye, The Constitutionality of DNA Sampling on Arrest, 10 CORNELL J.L. \& PUB. POL'Y _ (forthcoming 2001).

${ }_{11}$ Brief of Amicus Curiae, Institute for Science, Law and Technology, Illinois Institute of Technology at 30, Landry v. Attorney General, 709 N.E.2d 1085 (Mass. 1999); cf. Jonathan Kimmelman, Risking Ethical Insolvency: A Survey of Trends in Criminal DNA Databanking, 28 J. L. MED. \& ETHICS 209, 212 \& 215 (2000) (asserting that research uses of anonymized DNA data or samples taken without consent are ethically suspect). For a skeptical analysis of such assertions, see David H. Kaye, Bioethics, Bench, and Bar: Selected Arguments in Landry v. Attorney General, 40 JURIMETRICS J. 193 (2000).

${ }^{12}$ Mark A. Rothstein \& Sandra Carnahan, Legal and Policy Issues in Expanding the Scope of Law Enforcement DNA Data Banks, 67 BroOK. L. REV. 127 (2001) [hereinafter Legal and Policy Issues].

${ }^{13}$ Id. at 129 (footnote omitted).

${ }^{14}$ See infra Part III.

${ }^{15}$ Legal and Policy Issues, supra note 12 , at 130.

${ }^{16}$ Most of the nine commandments are unexceptional, but some seem arbitrary. For example, Rothstein and Carnahan urge that only buccal swabs be used to collect DNA even though they recognize that less intrusive procedures for sampling 
The objective is commendable, and, at first blush, the limitations seem eminently reasonable. However, there is little reason to restrict the data bases to profiles based only on loci in noncoding regions or to confine them to identifying profiles of only sexual offenders and violent felons. If anything, a highly secure population-wide data base of purely identifying information might well offer the best accommodation of the public and private interests in crime control and civil rights and liberties. ${ }^{17}$ But one need not go that far to see the fallacies or weaknesses in the Rothstein-Carnahan commandments. Part I of this Commentary explains why confining forensic loci to noncoding regions is neither necessary nor sufficient to protect privacy. It proposes a different standard-limiting identification profiles to loci that are not associated with any stigmatizing or socially meaningful phenotypes-that is better tailored to genuine privacy concerns. Part II shows that limiting the coverage of the data bases to sexual offenses and violent felonies would be unduly restrictive. It argues that while more research is needed if the data base laws are to select those crimes that are the most appropriate to trigger collection of DNA, there are clear indications that limiting coverage to violent felons significantly compromises the power

DNA are becoming available. Legal and Policy Issues, supra note 12, at 161 . They propose that "the data banks ... not be used for . . . research," but they do not define the types of research that they fear or indicate why this research is objectionable beyond the oversimplification that "government funded or sponsored research involving human subjects requires voluntary, informed consent." Id. at 164. No law or regulation requires informed consent in every circumstance, and it is well known that "[t]he role of informed consent has been much less clear for research that does not require such personal involvement but rather can be performed using tissue samples." Ellen Wright Clayton et al., Informed Consent for Genetic Research on Stored Tissue Samples, 274 JAMA 1786, 1786 (1995). Indeed, "[w]hether previously collected human biological materials may be used for newly conceived research has been the most controversial issue in research ethics for the past four years." Henry T. Greely, Breaking the Stalemate: A Prospective Regulatory Framework for Unforeseen Research Uses of Human Tissue Samples and Health Information, 34 WAKE FOREST L. REV. 737, 737 (1999). Subtleties in applying the so-called "Common Rule" for human subjects research expressed in the Code of Federal Regulations to convicted offender DNA samples are discussed in NATIONAL BIOETHICS ADVISORY COMMISSION, RESEARCH Involving Human BIological Materials: ETHICAL IsSUES AND POLICY Guidance, 28-32 (1999), and Kaye, supra note 11, at 213-14.

${ }^{17}$ See David H. Kaye \& Michael Smith, DNA Databases for Law Enforcement: The Coverage Question and the Case for a Population-wide Database, in THE TECHNOLOGY OF JUSTICE: THE USE OF DNA IN THE CRIMINAL JUSTICE SySTEM (David Lazer ed., forthcoming). 
of the data bases to identify perpetrators of both violent and nonviolent crimes and to deter criminal misconduct. Part III moves from these policy issues to the Fourth Amendment question. As Legal and Policy Issues indicates, the opinions of the Supreme Court this Term in City of Indianapolis $v$. Edmond ${ }^{18}$ and Ferguson $v$. City of Charleston ${ }^{19}$ undermine many lower court opinions holding that convicted-offender DNA data bases satisfy the Fourth Amendment. Consequently, I outline a theory that should permit carefully designed and administered identification data bases, including some that incorporate profiles from individuals other than convicted violent offenders, to pass constitutional muster.

\section{THE FALLACY OF NONCODING REGIONS}

Rothstein and Carnahan's discussion of their third commandment_to avoid coding $\mathrm{DNA}^{20}$-consists of essentially four sentences. First, they cite the "commonly raised objections .. . that samples could be analyzed to reveal future health risks and that this information might be disclosed to . . . insurers and employers." ${ }^{21}$ They do not discuss how realistic it is to imagine that insurers and employers will turn to the police to obtain DNA samples before insuring or hiring exconvicts. ${ }^{22}$ They do not mention that there are no known instances of such disclosure ever having occurred, that there are relatively few documented instances of insurers or employers using anyone's surreptitiously obtained DNA samples, ${ }^{23}$ and that there are a plethora of laws against "genetic discrimination." 24

${ }^{18} 531$ U.S. 32 (2000).

${ }^{19} 532$ U.S. 67 (2001).

${ }^{20}$ Rothstein and Carnahan define "the coding regions" to consist solely of exons. Legal and Policy Issues, supra note 12, at 162 n.208. An exon is "any segment of an interrupted gene that is represented in the mature RNA product." BENJAMIN LEWIN, GENES VI 1223 (1997).

${ }_{21}^{2}$ Legal and Policy Issues, supra note 12, at 158 (footnotes omitted).

${ }^{22}$ The concern is somewhat more powerful with respect to a population-wide repository of samples, but commandment three would apply regardless of coverage.

${ }^{23}$ See David H. Kaye, Respecting Genetic Privacy: A Foreword, 40 JURIMETRICS J. 1,6 n.26 (1999).

${ }_{24}$ See, e.g., William F. Mulholland, II \& Ami S. Jaeger, Comment, Genetic Privacy and Discrimination: A Survey of State Legislation, 39 JURIMETRICS J. 317 
Indeed, Rothstein and Carnahan admit that their concern lies more with public perception, even if unfounded, than with any genuine threat to personal privacy. ${ }^{25}$ Yet, it is not clear that the public objects to the use of certain coding regions. Fingerprints, for instance, have a genetic component, ${ }^{26}$ but the public is comfortable with this identification technology; there is no broad public demand for legislation to limit the government to collecting or storing data on only the nongenetic features of fingerprints. Ironically, commentators who insist that genetic information is particularly dangerous and demands special attention to protect privacy feed the public malaise with genetic technology, prompting even scholars like Professor Rothstein, who reject genetic exceptionalism, ${ }^{27}$ to try to justify legislation on the basis of intuitions about what the public wants rather than what would best serve the public.

This is not to say that public acceptability can or should be excluded from the legislative process. Politics, after all, is the art of the possible, but scholarship seeking to devise the best possible public policies should begin by examining the extent to which the suspected objections of the public are justified and should consider the possibility of educating the public rather than immediately capitulating to misunderstandings of science and its true privacy implications.

Second, Rothstein and Carnahan cite the less common objection that "the information could be used for research into purported genetic links to criminality. ${ }^{, 28}$ They do not assess the merit or plausibility of this objection, and it is doubtful that many geneticists believe that there are "crime genes" waiting to be discovered. Moreover, other than suggesting that the public does not like such research, they do not explain why-if it were scientifically valid-research in behavioral genetics should be shunned. One might think that the law should

(1999); Helen R. Davis \& Janis V. Mitrius, Note, Recent Legislation on Genetics and Insurance, 37 JURIMETRICS J. 69 (1996).

${ }_{25}$ See Legal and Policy Issues, supra note 12, at 159 n.200.

${ }^{26}$ See Simon A. Cole, Suspect IDENTITIES: A History of Fingerprinting AND CRIMINAL IDENTIFICATION 117 (2001).

${ }^{27}$ See Mark A. Rothstein, Why Treating Genetic Information Separately is a Bad Idea, 4 TEX. REv. L. \& PoL. 33 (1999).

${ }^{28}$ Legal and Policy Issues, supra note 12, at 158 (footnotes omitted). 
encourage rather than frustrate a better understanding of human behavior, ${ }^{29}$ but Rothstein and Carnahan would forbid all research undertaken with samples or data initially acquired for law enforcement purposes. Their ban would apply no matter how innocuous the research and no matter what procedures are followed to render samples or data anonymous, or to obtain consent from individuals whose profiles are stored. ${ }^{30}$

Third, Rothstein and Carnahan worry "that the information could be used for child support or immigration purposes." ${ }^{\prime 31}$ Are they concerned that a convicted offender who is named in a paternity suit (and hence subject to a court order to provide a DNA sample for parentage testing) will not have to provide a second sample because the first already is in a data bank and could be made available to the court? That a child of disputed parentage seeking to obtain citizenship could turn to an offender data bank to demonstrate that his father or mother is a U.S. citizen? If these are meaningful invasions of parental privacy-which I doubt ${ }^{32}$ - the obvious solution is to prohibit the disclosure of these samples or records even when a court would be willing to order a physical examination in the interests of civil justice.

Rothstein and Carnahan apparently find these and other unspecified "related concerns about improper uses of DNA samples"33 compelling, for the fourth step in their argument is the observation that these concerns "would be eliminated if only noncoding regions of DNA were analyzed and the samples were destroyed after analysis." ${ }^{34}$ However, this

${ }^{29}$ Cf. Owen D. Jones, Evolutionary Analysis in Law: Some Objections Considered, 67 BROOK. L. REV. 207 (2001).

${ }^{30}$ Relying on Kimmelman, supra note 11, at 212, they report that "[t]wenty states permit the use of samples for research." Legal and Policy Issues, supra note 12, at 164 n.216. However, "twenty states" does not refer to all research uses, and it does not refer to samples. Rather, Kimmelman reports that "twenty states ... authorize use of databanks for research on forensic techniques." Kimmelman, supra note 11, at 212 (emphasis added). Of the twenty states, it seems that fifteen only "allow release of records," and not samples. Id. The remaining five "appear to authorize release of DNA samples," but only for "identification research and protocol development." Id.

${ }^{31}$ Legal and Policy Issues, supra note 12, at 158-59 (footnote omitted).

${ }^{32}$ See Kaye, supra note 11.

${ }^{33}$ Legal and Policy Issues, supra note 12 , at 159.

${ }^{34} I d$. Of course, the same thing could be said about the hundreds of millions of DNA samples kept in public or private repositories. See NATIONAL BIOETHICS 
sanguine conclusion rests on the mistaken assumption that only the portions of genes that code for proteins or ribo-nucleic acid ("RNA") reveal information that an individual might have a right to keep secret. The fact is that some noncoding loci can indicate or predict disease states, ${ }^{35}$ and all loci, coding and noncoding alike, can be used for parentage testing. ${ }^{36}$

Thus, the noncoding commandment is not entirely satisfactory. Still, the desire to limit the government to portions of the genome whose revelation would not harm any meaningful individual interest (other than avoiding identification) is appropriate-and that is precisely the principle that Rothstein and Carnahan should embrace. It serves no clear purpose to bar access to loci that are not indicative of features of some social concern. Blood groups and serum proteins, for example, have long been used in forensic serology. Typing the loci that govern these phenotypes poses no new privacy issue and need not be banned. ${ }^{37}$ The public has not

ADVISORY CoMmission, supra note 16, at 13 (estimating that there were more than 282 million specimens of human biological materials stored in the United States in 1988, with samples from another twenty million individuals accumulating each year). The real issue is whether less drastic remedies would satisfy valid concerns about undesirable disclosures or uses of samples.

${ }^{35}$ A DNA sequence that is adjacent to an exon in which disease-producing alleles are common could be indicative or predictive of the disease. See Kaye, supra note 11 , at 201. For example, a condition known as G6PD deficiency causes anemia in 400 million people. Two of its many variants (the Med and A-variants) are strongly associated with certain microsatellites in the noncoding region of the G6PD gene. See Ann Gibbons, Studying Humans-and Their Cousins and Parasites, 292 ScI. 627, 628 (2001).

${ }^{36}$ Consequently, citing fears about the use of offender DNA samples or records for "child support or immigration purposes" as a reason to preclude coding loci makes no sense. All alleles inherited in a Mendelian fashion (including the noncoding STRs now used for offender databases) can be used for these purposes. See, e.g., R.L. Alford et al., Rapid and Efficient Resolution of Parentage by Amplification of Short Tandem Repeats, 55 AM. J. HUM. GENETICS 190 (1994); see generally Jeffrey W. Morris \& David W. Gjertson, The Scientific Status of Parentage Testing, in 1 MODERN ScIENTIFIC EvidENCE: THE LAW AND SCIENCE OF EXPERT TESTIMONY $§ \S 19.2$ \& 19.3 (David Faigman et al. eds., 1997).

${ }^{37}$ Rothstein and Carnahan contend that the overinclusiveness is not harmful because there are ample loci in noncoding regions, and the commandment to stay away from coding loci is costless. Legal and Policy Issues, supra note 12, at $159 \mathrm{n.200}$. But this rejoinder ignores their own assertion that one of the 13 CODIS STR loci is coding. $I d$. at $159 \mathrm{n} .199$. If this were so, then at a minimum, every federal, state, and local database would have to be redesigned to conform to the proposed no-coding directive. This would result either in a loss of statistical power to distinguish among individuals (if the offending STR data were purged) or retesting of hundreds of thousands of 
questioned the use of coding regions in forensic work, and public support of or opposition to offender data bases will not be substantially affected by the assurance that only noncoding loci-as opposed to coding loci that are as meaningless as fingerprints-will be used. ${ }^{38}$

Conversely, noncoding sequences that actually predict certain disease states should not be used in forensic data base work. Thus far, this is exactly what has occurred. The thirteen standard identifying loci used in the FBI's Convicted Offender DNA Index System ("CODIS") represent perhaps a millionth of the human genome. Contrary to the assertion in Legal and Policy Issues, all are noncoding, and none is known to correlate with any observable traits-stigmatizing or otherwise. ${ }^{39} \mathrm{~A}$

samples (to include additional loci). Furthermore, the argument cannot be reconciled with the claim that "additional research is likely to reveal both the functional and evolutionary significance of all human DNA." Id. at $162 \mathrm{n} .208$. If and when previously unknown functions for all DNA are identified, the bright line distinction between coding and noncoding regions will become meaningless.

However, it seems extremely improbable that all human DNA is functional, and most of it is not functional in any sense that meaningfully implicates personal privacy. See, e.g., LEWIN, supra note 20, at 703 (describing pseudogenes); Bob Kuska, Should Scientists Scrap the Notion of Junk DNA?, 90 J. NAT'L CANCER INST. 1032 (1998); Wojciech Makalowski, Genomic Scrap Yard: How Genomes Utilize All That Junk, 259 GENE 61 (2000). For example, some research indicates that certain repetitive, noncoding sequences play a crucial role in the process by which one of the two X chromosomes in a female is inactivated early in development. See Gretchen Vogel, Objection \#2: Why Sequence the Junk?, 291 ScI. 1194 (2001). Suppose that this inactivation is essential to the development of a viable fetus but that there are many nonlethal sequence variants in the female population. The loci would be "functional"they are necessary for proper development-but the polymorphisms in the population would not be.

${ }^{38}$ Rothstein and Carnahan present the statement of two FBI scientists that "[t]he majority of genetic markers used in DNA typing are noncoding segments" as if it somehow "endorsed" the exclusive "use of noncoding regions." Legal and Policy Issues, supra note 12, at 162 (citation omitted). These individuals do not endorse such a rule. Rather, they insist that the use of some coding loci in forensic work is not a problem because "the relative risk of the association is so low as to provide little or no information regarding an individual's health status or future well-being; the DNA types from coding marker data do not provide the level of information as, for example, the disease-causing gene itself." Randall S. Murch \& Bruce Budowle, Are Developments in Forensic Applications of DNA Technology Consistent with Privacy Protections?, in Genetic Secrets: Protecting PRIVACy and Confidentiality in the Genetic ERA 212, 224 (Mark A. Rothstein ed., 1997).

${ }^{39}$ See Kaye, supra note 11, at 201. Citing JoHN M. BUTLER, Forensic DNA TYPING: BIOLOGY AND TECHNOLOGY BEHIND STR MARKERS (2001), Rothstein and Carnahan assert that the CSF1PO microsatellite lies in a coding region. See Legal and Policy Issues, supra note 12, at $159 \mathrm{nn} .199-200$. Perhaps they misinterpreted the statement that "CSF1PO is a simple tetranuceotide repeat found in the c-fms proto- 
statutory proscription of coding loci would not be a disaster. But it is a second-best solution to a nonproblem. At best, it would offer the public a false sense of security. A standard aimed directly at the potential threat to personal privacy is a better means of protecting privacy.

\section{THE FALLACY OF SEXUAL OFFENDERS AND VIOLENT FELONS}

Rothstein and Carnahan's eighth commandment is that "DNA data banks should be limited to DNA obtained from individuals convicted of violent sex offenses and other violent felonies. ${ }^{90}$ This commandment incorporates two ideas: that only convicted offenders should have their identifying DNA profiles on file and that the only offenses that warrant collection of samples are violent felonies. Neither proposition is well defended. To determine the optimal scope of a data base, one would need to consider the favorable impact of the system on crime and law enforcement costs (the benefits) and the expenses of constructing and operating the system as well as the expected harms to individuals (the costs). ${ }^{41}$

Although Rothstein and Carnahan speak of the need to balance costs and benefits, ${ }^{42}$ they do very little balancing. They write that although it is "reasonable" to believe that "[t]he more samples in the data bank, the greater the likelihood of a match[,] . . . . there is little empirical evidence. ${ }^{\$ 3}$ However, all the available evidence suggests that a significant fraction of

oncogene for the CSF-1 receptor on the long arm of chromosome 5." BUTLER, supra, at 70. This description means that CSF1PO is a short segment of DNA (a "microsatellite") consisting of repetitions of the sequence AGAT. See id. at 274. The shortest allele has six repeats (AGATAGATAGATAGATAGATAGAT); the longest has sixteen repeats. Id. Such DNA variations are known as Short Tandem Repeats ("STRs"). Like four other STRs selected for use in CODIS, this one is located within a gene. But it lies within an intron, not an exon. Thus, as Butler clearly states, all "the 13 CODIS core STR loci are in noncoding regions...." $I$ d. at 245 .

${ }^{10}$ Legal and Policy Issues, supra note 12, at 165.

41 I do not mean to restrict "costs" to monetary matters. A violation of rights or individual interests that deserve protection counts as a cost.

${ }^{12}$ See Legal and Policy Issues, supra note 12, at 161 (quoting Jean E. McEwen, DNA Data Banks, in Genetic SECRETS: PROTECTING PRIVACY AND CONFIDENTIALITY IN THE GENETIC ERA 231, 236 (Mark A. Rothstein ed., 1997)).

${ }^{13} \mathrm{Id}$. at 158 (footnote omitted). 
sexual offenders have committed nonviolent offenses. ${ }^{44}$ Consequently, even if sex offenses were the only crimes for which DNA evidence is useful, failing to include all other types of convicted offenders drastically reduces the efficacy of the data bases. ${ }^{45}$ In addition, innovations in technology permit DNA evidence to assist in solving burglaries, auto thefts, and other crimes that once were thought not to yield traces of DNA. Entering homes, apartments, or cars to steal property often is repeated many times before an initial apprehension. While such property crimes generate DNA traces in a smaller fraction of the cases, they are so much more common than violent felonies that they have proved to be a rich source of "cold hits." This is clear even though no jurisdiction has exploited the full potential of DNA data bases to resolve nonviolent crimes.

${ }^{44}$ Studies show that convicted rapists released from prison are more likely to be re-arrested for crimes other than rape than they are for another rape. The Bureau of Justice Statistics examined the arrest records of a representative sample of all prisoners released in 1983 from prisons in eleven states. See LAWRENCE A. GREENFELD, U.S. DEP'T OF JUSTICE, SEX OFFENSES AND OFFENDERS: AN ANALYSIS OF DATA ON RAPE AND SEXUAL ASSAULT 26 (1997). During the three-year follow-up period, $7.7 \%$ of the 2,214 released rapists were re-arrested for another rape, but over five times this number (42.8\%) were re-arrested on other charges. Id. The rapists' re-arrest rates for other violent crimes were $2.8 \%$ for murder, $8.5 \%$ for robbery, and $10.7 \%$ for assault; the remaining $22.8 \%$ of the re-arrests were for nonviolent crimes. (The percentages relate to a base of 2,214 rapists who were studied.). Id. Apparently, rapists do not confine their criminal activities to rape and other violent offenses.

${ }^{45}$ See, e.g., Richard Willing, Study: Many Rapists Were Thieves First Results May Lead to Taking DNA for Lesser Crimes, USA TODAY, July 10, 2000, available at 2000 WL 5783383; Barbara Bradley, Profile: Use of a DNA Data Bank to Catch Criminals in Virginia, NAT'L PUBLIC RADIO, MORNING EDITION, Mar. 8, 2001, available at 2001 WL 9326731 (citing Paul Ferrara, the director of Virginia's Department of Forensic Science, as reporting that more than half the rapists caught in database searches were already in the data bank, not for sexual assault, but for burglary); Legal and Policy Issues, supra note 12, at 158 n.195 (acknowledging that " $52 \%$ of Florida offenders linked to sexual assaults and homicides by DNA data base matches had prior burglary convictions, a non-violent offense.").

${ }^{46}$ A "cold hit" is a match between a DNA profile derived from trace evidence and an exhaustive search of a database of profiles. By 1999, the United Kingdom's Forensic Science Service was able to develop a DNA profile in five percent of all property-crime samples, and most of the hits in the database for England and Wales now come from burglary and vehicle theft cases rather than from rapes or murders. See Werrett, supra note 4; see also Forensics Help Trap 1,000 Car Thieves, BRISTOL EVENING POST, June 27, 2001, at 7, available at 2001 WL 22486231. Likewise, 77\% of reported data base matches in New Zealand "have originated from burglaries." S.A. Harbison et al., The New Zealand DNA Databank: Its Development and Significance as a Crime Solving Tool, 41 ScI. \& JUST. 33, 36 (2001). 
In sum, there is plenty of empirical evidence that bigger data bases solve more crimes. ${ }^{47}$ Perhaps the clearest proof comes from the United Kingdom, where police take DNA profiles from all persons arrested for imprisonable offenses. Authorities there report a forty percent hit rate-four out of ten new crime scene samples checked against the data base match a previously recorded profile of an offender or suspect. ${ }^{48}$ It seems likely that limiting DNA data bases to violent felonies, as Rothstein and Carnahan propose, would severely compromise the power of these data bases to prevent crimes. ${ }^{49}$ And for what?

Surprisingly, Rothstein and Carnahan do not identify a single harm that would flow from including more felonies as qualifying offenses in a data base of purely identifying profiles. ${ }^{50}$ They do attempt to address a problem with expanding coverage outside the realm of convicted offenders, but that problem is remarkably amorphous or, to use their

${ }^{47}$ In the same breath that Rothstein and Carnahan dismiss the evidence on the value of including profiles from individuals convicted of nonviolent felonies in DNA databases, they note that in Virginia, "85\% of hits would have been missed if las they propose] the data bank were limited only to violent offenders." Legal and Policy Issues, supra note 12, at 158 n.195. Even so, they would be correct to complain that such studies are "limited" in the sense that they have been presented to the media and at professional meetings, but not, to my knowledge, in the peer-reviewed criminology literature. Moreover, statistics like those in Florida are hardly conclusive. The yield that follows from including the profiles of burglars depends on: (1) how many burglaries occur; and (2) how well an initial burglary predicts subsequent crimes (of all types) that might be solved with the aid of DNA evidence.

${ }^{48}$ Forensic Science Service, Press Release: Crime Reduction Model, July 14, 1999, available at http://www.forensic.gov.uk/forensic/news/press_releases/1999/007.htm.

${ }^{49}$ As criminals become more careful about leaving DNA traces, the databases could become less effective. See Richard Willing, Criminals Try to Outwit DNA, USA TODAY, Aug. 28, 2000, at A1. At this point, however, it seems premature to maintain that no state should experiment with (and carefully analyze the results of) incorporating in their databases profiles from at least some nonviolent felonies. $C f$. Press Release, Serial Burglar Caught by Pioneering Science, http://www.forensic.gov.uk/forensic/news/press_release/2001/04-05-2001.htm (last visited July 13, 2001 (reporting that an experimental project to detect nonviolent offenders led to the conviction of a burglar implicated in forty-three burglaries using a "DNA Low Copy Number" method and "local intelligence databases").

${ }^{50}$ A "purely identifying database" is one that uses loci of the type described in Part I and that effectively prevents unauthorized access to the original samples. The latter protection could be achieved by destroying samples, as advocated in Legal and Policy Issues, or by insulating police from the collection, analysis, and storage of samples, as discussed in Kaye \& Smith, supra note 17. 
term, "abstract.,"51 They assert that that biometric information trespasses into "a sphere of inviolability," disrupting "autonomy, dignity, and physical integrity", that " [t]he quality of a nation's civilization can be largely measured by the methods it uses in the enforcement of its criminal law;" ",53 that " ' $[t]$ he greatest dangers to liberty lurk in insidious encroachment by men of zeal, well-meaning but without understanding;' ${ }^{\prime 54}$ and that we should abjure comprehensive data bases for the same reasons we abhor coerced confessions. ${ }^{55}$

Conspicuously absent from these ringing phrases and strained analogies is a clear and convincing statement of the liberty or dignitary interests being threatened. It surely is not bodily integrity or freedom of movement. It would be easy (at least prospectively) to extract identification profiles as an adjunct to public health programs that screen DNA samples from almost all newborns, looking for treatable genetic diseases ${ }^{56}{ }^{5}$ The identification profiles could be transmitted to a single, secure, national, law enforcement data base. Unlike the offender data bases favored by Rothstein and Carnahan, in slowly assembling a population-wide data base, law enforcement agencies would not need-and should not be permitted-to handle, much less retain, the samples. Such a system would entail no further detention of the individual or invasion of the body. Neither is there any danger to the privacy of personally sensitive information. The data base profiles are and can continue to be limited to markers of purely biometric significance, represented in the data base records as a series of digits comparable to social security or passport numbers. What, then, is the offensive feature of this law enforcement procedure that makes it one of the "greatest threats to liberty"?

No answer is to be found in Legal and Policy Issues. The closest the article comes is an unexplored analogy to the practice of wiretapping. ${ }^{57}$ According to Rothstein and

${ }^{51}$ Legal and Policy Issues, supra note 12, at 166.
${ }^{52}$ Id. at 167.
${ }^{53}$ Id. at 166 (citation omitted).
${ }^{54}$ Id. at 169 (citation omitted).
${ }^{55}$ Id.
${ }^{56}$ See Phil Reilly, Legal and Public Policy Issues in DNA Forensics, 2 NATURE REVIEWS GENETICS 313, 315 (2001).

${ }^{57}$ Rothstein and Carnahan note that in 1943, the Senate did not act on a bill to establish a national fingerprinting system. Legal and Policy Issues, supra note 12, at 
Carnahan, the 1928 case of "Olmstead v. United States raises issues analogous to those we see today with DNA law enforcement data banks. ${ }^{\text {.58 }}$ But which issues are these? In Olmstead, the Court held, over Justice Brandeis's celebrated dissent, that wiretapping did not infringe the Fourth Amendment unless it entailed a physical trespass to private property. The unfettered ability of the police to listen to any conversation at any time in any place would greatly undermine any sense of confidentiality and security in private communications. In that context, Justice Brandeis's admonitions against insidious and overzealous steps toward a totalitarian regime are not merely stirring, but persuasive. But suitably designed DNA data bases do not interfere with personal communications, do not track a person's movements day and night, and (with the possible exception of genetic relatedness) do not reveal personally or socially sensitive qualities. Even a population-wide national data base would not resemble universal electronic surveillance.

It is not privacy in general that is put at risk when the state has an ability to match found DNA with a profile retained in an identification data base. It is not autonomy. It is not human dignity. It is the interest in disguising or altering one's identity. ${ }^{59}$ There is a largely unspoken assumption, deeply rooted in American history and culture, that if we are moved to do so, it is possible for us to leave the past behind and to reinvent ourselves in another place. But this a romantic, unrealistic prospect today. The lives we lead leave a trail in medical records, in credit card records, in school records, in employment files-in any records that link to our social security numbers, drivers' license numbers, and the like. We can be found if the state, or anyone with means, really cares to find us.

160 n.204. Earlier efforts also were unsuccessful. See Bills in Congress re Fingerprinting, 32 J. CRIM. L. \& CRMINOLOGY 656 (1942).

${ }_{58}$ Legal and Policy Issues, supra note 12, at 168 (citation omitted).

${ }^{59}$ I am grateful to Michael Smith for framing the issue in this way, and this paragraph and the next borrows liberally text he prepared for Kaye \& Smith, supra note 17. 
We may resist acknowledging that anonymity is no longer feasible, and we may be tempted to portray it as a fundamental right guaranteed by the Constitution. ${ }^{60}$ But the interest in changing or obscuring one's identity is not a constitutionally recognized or morally profound interest. It may be desired by many people intent on committing crimes; surely, it is a rare offender who expects to be identified and apprehended when he or she commits a crime. If no one knows who they are, these offenders may well elude apprehension; conversely, there is no special trick to apprehending a burglar, a robber, or a hit-and-run driver whose name can be given to police by a passerby. A comprehensive DNA identification data base reduces such anonymity for offenders-and for the rest of us. Still, it seems that anonymity and the opportunity to take on a new identity is of little practical importance unless we want to commit crimes. If so, those who would oppose a comprehensive identification data base simply to honor the desire for an unstable identity are left in the awkward position of opposing a program that protects everyone from the most serious threats to their lives and well-being for the stated reason that its existence would make it harder to pursue a life of crime. ${ }^{61}$

In urging the narrowest plausible scope for DNA data bases, Legal and Policy Issues also ignores an issue of supreme importance in the design of law enforcement data bases. Because most convicted felons (and most arrestees) are minority citizens, ${ }^{62}$ including individuals on the basis of conviction (or arrest) generates a racially skewed collection of DNA profiles. In some states, one in seven African-American males are incarcerated before the age of eighteen, compared

${ }^{60}$ Obviously, I am speaking of anonymity as to one's identity in general. Anonymity may be personally or socially valuable in certain contexts, such as making charitable donations or expressing unpopular opinions. A population-wide DNA database for law enforcement purposes would not be a serious threat to maintaining anonymity in these situations.

${ }_{61}$ Of course, the future could bring laws we think it right to violate, even a state that deserves to be overthrown. There is no denying that a comprehensive DNA identification database would reduce the anonymity essential for successful revolutionaries.

${ }_{62}$ In 2000 , there were some 663,700 white inmates of prisons and jails compared to 791,600 African-Americans and 290,000 Hispanic-Americans. ALLEN J. BECK \& JENNIFER C. KARBERG, PRISON AND JAIL INMATES AT MidYEAR 2000, at 5, tbl. $12(2001)$. 
with 1 in 125 white males. ${ }^{63}$ Nationally, the percentage of adult black men under correctional supervision of one kind or another is four times higher than the corresponding percentage of white men. ${ }^{64}$

Creating a hodgepodge of DNA data bases on the basis of contacts with police, prosecutors and judges is sure to compound the racial polarization of our criminal justice system, while foregoing the deterrent and investigative capability that a population-wide data base would afford. Any effective data base will lead to increased rates of detection and conviction for the individuals whose DNA types are on file.

* See Heidi M. Hsia \& Donna Hamparian, Disproportionate Minority Confinement: 1997 Update, JUVENILE JUSTICE BULLETIN 1 (Sept. 1998). Statewide studies of incarceration in juvenile corrections facilities show that African-American youth have the highest confinement rates. See id. "[N]early seven out of ten youth in secure confinement are minority juveniles-a rate more than double their percentage in the youth population." Patricia Devine et al., Disproportionate Minority Confinement: Lessons Learned from Five States, JUVENILE JUSTICE BULLETIN (Office of Juvenile Justice and Delinquency Prevention, U.S. Dep't of Justice), Dec. 1998, at 1.

${ }_{64}$ See Allen J. Beck, Trends in U.S. Correctional Populations, in THE DILEMMAS OF CORRECTIONS: CONTEMPORARY READINGS (K.C. Haas \& G.P. Alpert eds., 4th ed. 1999). This figure is derived from the following data:

Percentage of Men Under Correctional Supervision by Race and Age, United States, 1996

\begin{tabular}{|c|c|c|}
\hline Age & $\begin{array}{l}\text { Percent of white men } \\
\text { in age category }\end{array}$ & $\begin{array}{l}\text { Percent of black men } \\
\text { in age category }\end{array}$ \\
\hline $18-19$ & 4.4 & 16.2 \\
\hline $20-24$ & 8.0 & 29.4 \\
\hline $25-29$ & 7.1 & 28.9 \\
\hline $30-34$ & 5.8 & 24.4 \\
\hline $34-39$ & 4.4 & 17.2 \\
\hline 40 or older & 1.3 & 6.1 \\
\hline
\end{tabular}

These figures pertain to all felons (and some misdemeanants), but the pattern of gross overrepresentation of minorities in the criminal justice and correctional systems predates the modern, highly punitive drug laws that many observers believe have contributed to an excessive rate of incarceration of African-Americans for nonviolent conduct. See, e.g., MichaEl TONRY, MALign NEGlect-RACE, CRIME, AND PUNISHMENT IN AMERICA 56-68, 104-16 (1995). 
From the standpoint of individual justice, it does not matter that the nonwhites will be affected disproportionately-it is not unfair to punish those who commit crimes. From the perspective of comparative justice, however, it is problematic to adopt a system that we know will fall more harshly on blacks and other minorities.

A comprehensive DNA data base not only directly satisfies the demand for comparative justice, but it could act as a mild antidote to conscious or unconscious racial biases. DNA evidence does not care about race. A data base profile either does or does not match a crime scene sample. With a population-wide data base, the identity of any matching individual would be known-irrespective of race. When a person is arrested and incriminating crime scene DNA evidence points to another person whose DNA profile is in the data base, prompt exoneration and release of the innocent is likely to follow-no matter what the initial suspect's race or status. If an innocent defendant does go to trial in such a case, the crime scene DNA evidence and the results of the data base search would be available, regardless of the defendant's race, to raise reasonable doubt about guilt. There would be no need to resort to racially focused or other forms of "DNA dragnets" of entire neighborhoods ${ }^{65}$ and less chance for racial prejudices or stereotypes to lead ordinary investigations astray. ${ }^{66}$

${ }^{65}$ For accounts of police efforts to collect DNA samples from large numbers of men in geographic locales to generate investigative leads, see Philip P. Pan, Pr. George's Chief Has Used Serial Testing Before; Farrell Oversaw DNA Sampling of 2,300 in Fla., WASH. POST, Jan. 31, 1998, at B1 (reporting that the San Diego police department "tested about 800 men during its search for a serial killer who stabbed six women to death in their homes between January and September 1990 . . . . [P]olice canvassed neighborhoods around the crime scenes and asked men matching a general description of a dark-skinned male provided by a witness to voluntarily provide blood or saliva samples. . . The killer, a 23-year-old laborer named Cleophus Prince now on death row, declined along with several other men to provide a sample. He later was arrested for breaking into another woman's home and agreed to provide a DNA sample-which matched evidence found at one of the murder scenes."); Alice Robinson, DNA of Innocent Rape Suspects Will Not be Kept: Ann Arbor Resident Filed Civil Lawsuit that Spurred Ruling, MICH. DAlLY ONLINE (Nov. 21, 1997), at http://www.pub.umich.edu/daily/1997/nov/11-21-97/news/news12.html (last visited Dec. 11,1998 ) (reporting that in 1994, police in Ann Arbor investigating a series of rapes collected blood samples from 160 African-American men in the area).

${ }^{66}$ Rothstein and Carnahan point out that "[i]t is not necessary to know the identity of the perpetrator to exonerate an innocent person charged with the crime." Legal and Policy Issues, supra note 12 , at $165 \mathrm{n} .218$. The situation is more complex. 
Legal and Policy Issues dismisses this concern with racial equality as "close to obfuscating."67 Expressing indignation over "dragnet searches" of large numbers of minority men (and women), ${ }^{68}$ the Article proposes, without a shred of explanation, that "dragnet searches of minority populations to generate suspects are unconstitutional under Davis v. Mississippi, 394 U.S. 721 (1969), and should be prohibited." "Without the outrage of such searches," Rothstein and Carnahan write, "Professor Kaye's 'equality' argument in favor of a national databank collapses." ${ }^{.70}$ Would that this were so. Not only is this reading of Davis impossible to support, ${ }^{71}$

Too many convicted offenders apparently exonerated by DNA testing have discovered that nothing less than iron-clad proof of the identity of the actual offender will secure their release. See Akhil Reed Amar, A Safe Intrusion, AM. LAW., June 11, 2001; Akhil Reed Amar, Foreword: the Document and the Doctrine, 114 HARV. L. REv. 26, 126 (2000). But even if one dismisses this problem as limited to the post-conviction phase in which prosecutors and police are loathe to revise their thinking, a DNA-based exoneration is not always possible. The sample size may be too limited to allow complete typing, and the few loci that are typed may not suffice to exclude the innocent suspect. In this situation, the database would expand the pool of identifiable suspects, making a correct outcome much more likely. In other cases, the police may not put in the effort required to collect a usable crime scene sample, especially when it is not obvious that there is a sample to be found. In these situations, a population-wide DNA. database could be helpful because the very existence of such a powerful crime-solving tool maximizes the incentive for police to obtain crime-scene DNA evidence. Finally, and most important in terms of the analysis here, the population-wide database often will enable the investigation to proceed in the right direction from the outset, reducing the total number of people subjected to ordinary investigations-which are potentially intrusive and, too often, unduly affected by racial considerations.

${ }^{67}$ Legal and Policy Issues, supra note 12, at 165 n.218.

${ }^{63} I d$.

${ }^{69} I d$.

${ }^{70} I d$.

71 In Davis, police in Meridian, Mississippi, questioned dozens of young blacks in response to a rape that the victim said was committed by "a Negro youth." 394 U.S. at 722. Their investigation of the home where the rape occurred revealed fingerprints on and nearby the window. Id. Acting "without warrants, [they] took at least 24 Negro youths to police headquarters where they were questioned briefly, fingerprinted, and then released without charge." Id. One of these was a fourteen-year-old boy who they later took, again without probable cause or a warrant, to a jail in Jackson, ninety miles away. There, police took a second set of finger prints and confined him overnight. After the FBI, which examined the boy's prints taken in Jackson as well as those of twentythree other suspects, reported that they matched the latent prints taken from the window, Davis was indicted, tried, and convicted for the rape, Although Davis objected at trial that the finger prints should be excluded as the product of an unlawful detention, this evidence was admitted. Id. at 723. The Supreme Court reversed this conviction. 
but the racial justice argument is much deeper and far more disturbing. It is this: in this country at this time, any law enforcement data base confined to convicted offenders (or other people suspected of crimes) will be populated disproportionately, and perhaps predominantly, by profiles from minority groups. The reasons for the disparate effect may be legitimate, or they may be nefarious, but this corrosive

At no point did anyone even question the fact that the police "dragnet" was directed at young blacks. Nothing in Justice Brennan's opinion for the majority (or any other opinion in the case) suggests that the Constitution prevents police from focusing an investigation on individuals of one race once the evidence shows that criminal conduct was committed by a person of that race. (For an analysis of the equal protection implications of this standard police practice, see Edward J. Imwinkelried \& David H. Kaye, DNA Typing: Emerging or Neglected Issues, 76 WASH. L. REV. 413 (2001)).

The constitutional evil in Davis was quite different. It was the lack of a warrant and individualized suspicion to detain the defendant and subject him to custodial interrogation. It was not the process of fingerprinting per se that bothered the Court. To the contrary, Justice Brennan suggested that probable cause might be unnecessary because fingerprinting is not a significant invasion of privacy. 394 U.S. at 727. The solitary basis for the reversal was that "no attempt was made here to employ procedures which might comply with the requirements of the Fourth Amendment: the detention at police headquarters of petitioner and the other young Negroes was not authorized by a judicial officer; petitioner was unnecessarily required to undergo two fingerprinting sessions; and petitioner was not merely fingerprinted during the December 3 detention but also subjected to interrogation." Id. at 728 .

The mass DNA screens, whether they focus on African-Americans or any other subpopulation, do not suffer from this infirmity. Nothing in the Fourth Amendment prevents the police from approaching everyone in a community and asking for their cooperation. The "dragnet" nature of the inquiry is no obstacle. Cf. United States v. Dionisio, 410 U.S. 1 (1973) (finding no infirmity in issuing, without probable cause, grand jury subpoenas to twenty men to secure voice exemplars from them). A consensual contact between a police officer and a citizen is neither a search nor a seizure under the Fourth Amendment. Cf. Davis, 394 U.S. at 727 n.6 (1969) (referring to "the settled principle that while the police have the right to request citizens to answer voluntarily questions concerning unsolved crimes they have no right to compel them to answer"). As a legal matter, police may ask anyone and everyone to give DNA; as long as they do not engage in coercion or misrepresentation, the police may collect voluntary samples for analysis. Although one might wish to argue that police requests for DNA are inherently coercive, the settled doctrine is that whether a particular contact involves coercion or misrepresentation is a matter of fact to be determined under the totality of the circumstances. See, e.g., Schneckloth v. Bustamonte, 412 U.S. 218 (1973).

The upshot of this standard analysis is that one would be sorely and sadly mistaken to rely on Davis for protection against police asking individuals of a single race or of many races to provide a DNA samples. In contrast, a population-wide data base would remove the incentive for police who are stymied in their efforts to solve serial killings or rapes to resort to neighborhood-wide or race-specific mass DNA screenings. 
outcome is assuredly not the result of recent and infrequent DNA "dragnets."

It is not obfuscating, but vital, to recognize that privacy and equality are deeply intertwined considerations in devising structural rules for law enforcement data bases. No set of rules should be formulated without attending to the equality strand along with the privacy issues. Of course, when all is said and done, the policy prescriptions of Legal and Policy Issues might be exactly right. It may be that the privacy concerns are so substantial and the equality concerns so flimsy that only the identifying profiles of violent felons should be included in law enforcement data bases. However, Rothstein and Carnahan do not demonstrate this point, for they confuse the desire for anonymity with more deserving facets of privacy, and they largely ignore the racial disparities implicit in an offender-only data base.

\section{THE IMPACT OF EDMOND AND FERGUSON}

In addition to promulgating public policy pronouncements, Rothstein and Carnahan skillfully dissect the case law on the constitutionality of law enforcement DNA data bases. Here, their conclusions are more circumspect. They cautiously write that "the outcome of a court challenge to a broader data bank law must be viewed as unclear at this time," but "it is possible that [expanded data banking] might be held constitutional" ${ }^{73}$ by the Supreme Court. Their summary of the case law is generally accurate and perceptive, ${ }^{74}$ and it raises a perplexing question: how can any law enforcement DNA data bank be deemed constitutional in the wake of the Supreme Court's recent opinions in City of Indianapolis $v$. Edmond ${ }^{75}$ and Ferguson v. City of Charleston ? $^{76}$

Before the last Term, the Supreme Court had applied the "special needs" doctrine to a wide variety of government programs, from municipal housing inspections, to inspections

\footnotetext{
${ }^{72}$ Legal and Policy Issues, supra note 12 , at 130.

${ }^{73} \mathrm{Id}$.

${ }^{74}$ However, there are opportunities for quibbling. See, e.g., infra note 96.

${ }^{75} 531$ U.S. $32(2000)$.

${ }^{76} 532$ U.S. 67 (2001).
} 
of motor vehicles at border checkpoints, to random drug testing of employees. ${ }^{77}$ In these cases, the Court reasoned that "neither a warrant nor probable cause, nor, indeed, any measure of individualized suspicion, is an indispensable component of reasonableness in every circumstance." ${ }^{\prime 78}$ Rather, as the Court explained the exception in National Treasury Employees Union v. Von Raab: $:^{79}$

[O]ur cases establish that where a Fourth Amendment intrusion serves special governmental needs, beyond the normal need for law enforcement, it is necessary to balance the individual's privacy expectations against the Government's interests to determine whether it is impractical to require a warrant or some level of individualized suspicion in the particular context. ${ }^{80}$

Many courts invoked this somewhat ill-defined doctrine to uphold the data base statutes requiring convicted offenders to provide DNA samples. ${ }^{81}$

As Rothstein and Carnahan demonstrate, however, Edmond and Ferguson confine the special needs doctrine to programs of searches and seizures adopted for a primary purpose other than catching or deterring offenders, effectively pulling the rug out from under the earlier data base cases. In Edmond, the Court declined to apply the special needs exception to a program in which police used dogs to sniff for drugs in vehicles pulled over in groups at fixed roadblocks. Distinguishing sharply between "highway safety interests and the general interest in crime control, ${ }^{, 82}$ the majority reasoned that "[b]ecause the primary purpose of the Indianapolis narcotics checkpoint program is to uncover evidence of ordinary criminal wrongdoing, the program contravenes the Fourth Amendment." Likewise, in Ferguson $v$. City of Charleston, ${ }^{84}$ the Court invalidated a program in which a state university hospital tested urine samples from pregnant women

\footnotetext{
${ }^{37}$ See, e.g., Kaye, supra note 10.

${ }^{78}$ Nat'l Treasury Employees Union v. Von Raab, 489 U.S. 656, 665 (1989).

${ }^{79}$ Id.

${ }^{80} I d$. at $665-66$.

${ }^{81}$ See Legal and Policy Issues, supra note 12, at 138.

${ }^{82}$ Edmond, 531 U.S. at 40.

${ }^{83}$ Id. at $41-42$.

${ }^{84} 532$ U.S. 67 (2001).
} 
for cocaine and reported positive results to the police so that those women, fearing prosecution, would be induced to participate in substance abuse counseling offered as an alternative to criminal prosecution. Again, the majority of the Court emphasized "the relevant primary purpose"-which was said to be "the arrest and prosecution of drug-abusing mothers. $" 85$

It does not follow, however, that "crime control and investigation [are] now an unconstitutional 'primary purpose' under Edmond and Ferguson." public security and the general welfare remains a legitimate constitutional power of government. In the aftermath of Edmond and Ferguson, three arguments might be adduced to justify the exercise of this power to construct and operate DNA data bases. ${ }^{87}$

\section{A. The Flanking Maneuver: Subsequent Use Is Not A Search}

One argumentative strategy is an end run around the warrant requirement that proceeds in two giant steps. The first step is to justify the acquisition of the DNA samples by relying on the "true identity exception." ${ }^{88}$ This exception allows police to acquire a record of a physical feature that identifies a person. Any biometric identifier-photographing, fingerprinting, DNA typing-any process that painlessly records purely physical features that help to establish the true identity of a person who might be using an alias-falls within this exception. If the person is legitimately detained (as in a valid custodial arrest), police can acquire the biometric identifier so they know who they are detaining and who might be apprehended again in an escape or a subsequent encounter. ${ }^{89}$

\footnotetext{
${ }^{85} I d$. at 74 (citation omitted).

${ }^{85}$ Legal and Policy Issues, supra note 12, at 155.

${ }^{87}$ Such arguments are developed at greater length in Kaye, supra note 10.

${ }^{\mathrm{B}} \mathrm{Id}$.

${ }^{89}$ See 3 Wayne LaFave, Search and SeIzURE: A Treatise ON THE
} FOURTH AMENDMENT § 5.3(c) (3d ed. 1996) ("Fingerprinting, as a routine part of the booking process, is justified by the legitimate interest of the government in knowing for an absolute certainty the identity of the person arrested, in knowing whether he is wanted elsewhere, and in ensuring his identification in the event he flees prosecution, 
This is the principle that underlies the early cases on photographing and fingerprinting arrestees. ${ }^{90}$

This "true identity exception" is subtly different from "the identification exception" $"$ described by Rothstein and Carnahan. According to Rothstein and Carnahan, "fingerprints or photographs" are "non-invasive administrative means of identification" that simply do not "implicate the Fourth Amendment"92 and that appropriately advance "the state's interest in preserving a permanent identification record of convicted offenders to resolve past and future crimes. ${ }^{\text {} 93}$ While the degree of the intrusion certainly is a consideration, the initial cases holding photography and fingerprinting constitutional did not reason that these procedures were not searches. Rather, they stated that these identification procedures were reasonable interferences with personal liberty or privacy. ${ }^{94}$ Moreover, the original true identity exception did not contemplate using the biometric data to link individuals to find the perpetrators of unsolved crimes. ${ }^{95}$ The exception was simply a response to the need for a reliable means of determining the criminal history of arrestees.

Thus, the true identity exception, as established before the DNA data base cases of the 1990s, does not justify the creation and use of a data base. That requires the second step. The argument here is that once the police have a program in place whose primary purpose is the administrative one of maintaining. a record of an individual's true identity, they can make a secondary use of the record to investigate unsolved crimes. ${ }^{96}$ They can show a witness mug shots or search a data

but there is no need for the government to establish any of these needs on a case-by-case basis.").

${ }^{90}$ See Kaye, supra note 10 (collecting these cases).

${ }^{21}$ Legal and Policy Issues, supra note 12, at 144, 155.

${ }^{92}$ Id. at 155.

${ }^{33}$ Id. at 146 (describing "the identification exception" as articulated in Landry v. Attorney General, 709 N.E.2d 1085, 1092 (Mass. 1999)).

${ }^{94}$ See Kaye, supra note 10.

${ }^{95} \mathrm{Id}$.

${ }^{96}$ Although it does not affect this second step in the flanking maneuver, it is worth commenting on Rothstein and Carnahan's claim that "the Supreme Court has recognized that a laboratory analysis of blood and other bodily fluids constitutes a 'second search' subject to the Fourth Amendment's reasonableness requirement." Legal and Policy Issues, supra note 12, at 156-57. They find this recognition in Skinner v. Ry. Labor Executives' Ass'n, 489 U.S. 602 (1989). Id. at 157 n.190. But Skinner does not go 
base of fingerprints or DNA profiles in the hope of generating investigative leads. These are not new searches. They are uses of legitimately acquired records that do not infringe on the interests of an individual-other than the obvious one of not being caught or suspected of the crime. ${ }^{97}$

However, in light of Edmond and Ferguson, it is crucial to the flanking maneuver that ascertaining an individual's true identity is the primary purpose and that trawling the data base for investigative leads is secondary. For DNA data bases, this claim is likely to be extremely implausible. The legislative interest in DNA data bases has not been primarily to supplement or supplant fingerprints as markers of true identity; it has always been to generate investigative leads.

\section{B. The Frontal Assault: Edmond and Ferguson Are Wrongly Decided}

A second response to Edmond and Ferguson would be to question the primary purpose test established in these

\footnotetext{
this far. The majority there did not write that the laboratory analysis of a urine sample was, in itself, a search. It discerned a search in light of the invasion of informational privacy arising from the laboratory analysis only when combined with the intrusiveness of obtaining the urine sample. The Court emphasized that "[t]here are few activities in our society more personal or private than the passing of urine. Most people describe it by euphemisms if they talk about it at all. It is a function traditionally performed without public observation; indeed, its performance in public is generally prohibited by law as well as social custom." Skinner, 489 U.S. at 617 (quoting Nat'l Treasury Employees Union v. Von Raab, 816 F.2d 170, 175 (5th Cir. 1987)). On this basis, and not because the laboratory work standing alone was a search, the Court concluded: "Because it is clear that the collection and testing of urine intrudes upon expectations of privacy that society has long recognized as reasonable, the Federal Courts of Appeals have concluded unanimously, and we agree, that these intrusions must be deemed searches under the Fourth Amendment." Id. at 617 (emphasis added). Perhaps the Court's language was meant to assert that taken separately, "collection and testing" each constitute a search, but this is not clear from the text or structure of the majority opinion. The Skinner Court was not confronted with the question of whether a laboratory analysis of a legitimately acquired sample is a "second search," and lower courts have concluded that it is not. See Patterson v. State, 742 N.E.2d 4 (Ind. Ct. App. 2000); Wilson v. State, 752 A.2d 1250 (Md. Ct. Spec. App. 2000).

${ }^{97}$ Conceivably, Rothstein and Carnahan mean to capture this two-step reasoning in their references to an undifferentiated "identification exception." However, it is not clear that the second step is consistent with the theory in Harold J. Kent, Of Diaries and Data Banks: Use Restrictions Under the Fourth Amendment, 74 TEX. L. REv. 49 (1995), on which they rely. See Legal and Policy Issues, supra note 12, at $157 \mathrm{n} .191$.
} 
opinions. In constitutional law, the analysis of legislative motivation is a perennially vexing problem, and today's majority view could become tomorrow's dissent. ${ }^{98}$ The only coherent rationale for the special needs exception is that the usual balance of individual and government interests, which results in a per se rule against warrantless searches (riddled with categorical exceptions), does not apply when the usual government interest in law enforcement is reinforced by special needs. ${ }^{99}$ As such, it can be argued that the special need to maintain a record of the true identity of individuals who are detained by the police arguably transports the situation outside the realm of the per se rule and justifies the type of balancing permitted under the special needs exception. If accepted, this line of argument might justify carefully constructed programs of compulsory DNA sampling on arrest, but aspects of a population-wide data base would remain constitutionally problematic. ${ }^{100}$

\section{The Solution: A New Biometric Identification Exception}

The flanking maneuver works in theory, but fails in practice. The frontal assault requires the Court to reconsider its two most recent encounters with the special needs exception, and that is not an especially likely prospect. The result, it seems, is that all law enforcement DNA data bases are unconstitutional regardless of how minimally invasive or intrusive they are and how much they contribute to the enforcement of the criminal law. To escape from this dilemma, a third response to Edmond and Ferguson should be considered. Rather than attempting an end run or trying to force DNA sampling into the special needs mold, it is time to harmonize the early line of cases on fingerprinting and photographing detainees with the modern cases on DNA data banking by crafting a new biometric identification exception.

${ }^{98}$ Both cases were decided by six-to-three margins.

${ }^{99}$ See Kaye, supra note 10.

${ }^{100}$ Because the primary purpose of taking DNA from newborns is to identify treatable genetic conditions such as phenylketonuria ("PKU"), and not to solve crimes, a population-wide database built prospectively from these samples might not run afoul of Edmonds and Ferguson. See David H. Kaye et al., Is a Population-Wide DNA Identification Database in Our Future?, _ CRIM. J. BULL. _ (forthcoming 2001). 
DNA data bases can do much more than discern an individual's true identity. They can associate individuals with crimes. A cogent argument can be made for a new exception to the warrant requirement for the relatively nonintrusive collection of nonstigmatizing, personally identifying markers that can generate a list of probable perpetrators of serious crimes. The Reasonableness Clause of the Fourth Amendment permits such an exception-depending on the balance between the nature and extent of the infringement of the individual's privacy on the one hand, and the value of having a data base of genotypes on the other. Elsewhere, I have begun to describe this balancing as it applies to arrestees ${ }^{101}$ and members of the larger public. ${ }^{102}$ The outcome of the balancing surely is debatable, and it will turn, among other things, on the privacy protections incorporated in each statute. But addressing the direct question of whether there should be a new exception to warrant and probable cause requirements will provide the most satisfactory approach to resolving the tension between the Court's two latest special needs cases and the last decade's worth of DNA data base cases.

\section{CONCLUSION}

The choices made in designing law enforcement data bases will have major repercussions on public safety, privacy, and equality. Not all aspects of "the freedom to be left alone,"1103 or even "the freedom to be left alone from governmental demands for bodily specimens ${ }^{\prime 104}$ are equally momentous. Limiting data bases to profiles of those who have been convicted of violent felonies privileges a form of privacy of relatively little value. At the same time, this coverage would surely perpetuate a system of racially skewed data bases and greatly curtail the capacity of this identification technology to prevent widespread, major crimes. Counteracting important threats to fundamental privacy interests would justify such a

\footnotetext{
${ }^{101}$ See Kaye, supra note 10.

${ }^{102}$ See Kaye \& Smith, supra note 17.

${ }^{103}$ Legal and Policy Issues, supra note 12, at 167.

${ }^{104}$ Id.
} 
policy choice, but the dangers posed by properly constructed and administered identification data bases do not.

Paradoxically, a carefully constructed and administered population-wide data base may offer the greatest privacy protection for all of us. Such a system need not involve the police or the criminal justice system to determine whose samples are collected and to acquire, analyze, and store the vast bulk of those samples. Furthermore, including every citizen's profile avoids the public attitude that the system is for "them," not "us," and hence that abuses will affect only criminals, not the rest of us. As a result, it would force the legislative and executive branches to take the greatest care in fashioning and implementing the system so as to protect privacy.

Even so, it may be tempting to dismiss a populationwide data base as impracticable, politically impossible, or unconstitutional. I believe that these judgments are premature, but even if they are correct, it could be equally ineffectual to insist that existing data bases be confined to a small subset of offenders. Given the enormous momentum of the movement to expand data base coverage at least with regard to categories of convicted offenders, it would be politically astute to focus reform efforts on the other matters raised in Legal and Policy Issues and in this commentary. Who should have access to the data bases and the samples from which they are derived? For what purposes? Should the samples and the data be retained indefinitely? Should the samples be retained at all? Should the profiles of past offenders be available for any use other than to check against crimescene samples? What constraints should be codified in statutes as opposed to regulation? As Legal and Policy Issues reminds us, there is ample room to improve the content and drafting of many DNA data base statutes. 